\title{
New mothers and their understanding about breast milk donation
}

Naiana Mota Buges 1

(iD) https://orcid.org/0000-0003-1222-205X

Karylleila dos Santos Andrade Klinger 2

(iD) https://orcid.org/0000-0001-6920-9206

Renata Junqueira Pereira 3

(iD) https://orcid.org/0000-0001-9487-4013

1-3 Universidade Federal do Tocantins. Campus de Palmas. Quadra 109. Palmas, TO, Brasil. CEP: 77.001-090. E-mail: renatajunqueira@uft.edu.br

\begin{abstract}
Objective: to analyze the understanding of mothers about the donation of human milk.

Methods: a qualitative and quantitative study with 13 potential milk donors who answered a sociodemographic and obstetric background questionnaire, as well as a semistructured interview guide on milk donation. Mothers were approached in the hospital environment, after delivery and the visit of the milk bank. Data were analyzed in Statistical Package for Social Sciences 20.0 and NVivo 11 Starter.

Results: the mean age was $24.62 \pm 3.95$ years; $84.6 \%$ had more than eleven years of formal education; $38.5 \%$ declared themselves housewives; $46.2 \%$ were in a stable union and $76.9 \%$ had an income of up to two minimum wages. Most of the mothers (69.2\%) experienced previous pregnancy; $76.9 \%$ had 6 or more prenatal consultations and $62.5 \%$ had previously breastfed. The motivating factors of the donation were altruism; empathy with other mothers; recognition of the primacy of breast milk; the child's understanding of breast milk need; excess milk production and family support. Unawareness of the process, limited time available, and lack of transportation and collection points can make donation difficult.

Conclusions: there was a desire for information and support for breastfeeding and donation, which made the donation act complex and distant from reality
\end{abstract}

Key words Donations, Milk human, Milk banks

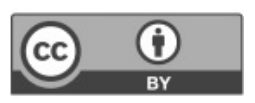




\section{Introduction}

The act of donating milk gained notoriety with the emergence of the Human Milk Banks (HMB). The first was opened in 1943 in Rio de Janeiro, at the then National Institute of Childcare, now the Instituto Fernandes Figueira (IFF), considered a reference center until nowadays for the others in Brazil. 1

With the development of the National Breastfeeding Incentive Program, especially since 1985, the HMB began to assume a new role in Brazilian public health scenario, becoming strategic elements for actions to promote, to protect and to support breastfeeding. 2,3

The National Network of Human Milk Banks in Brazil (NNHMB) is the largest and best structured network of HMB in the world. It currently has more than $224 \mathrm{HMB}$ and 217 collection points, spread across the country, with the purpose of promoting, protecting and supporting breastfeeding (BF), conducting collection and distributing certified quality human milk (HM), thus contributing to reduce infant mortality. ${ }^{4}$

The benefits arising from breast milk (BM) are indisputable, it is considered essential to have $\mathrm{HM}$ in volume that makes it possible to attend, in urgent cases, all infants who, due to clinically proven circumstances, cannot breastfeed on occasions for which HMBs are a solution. 5

The donation of HM is a voluntary act, which can be performed by healthy breastfeeding mothers who have excess milk production, in addition to the normal needs of the child. ${ }^{1}$ Although there is widespread disclosure in the media and health services about the importance of donation of HM, the number of donations is still low and the HMB reach approximately $60 \%$ of the demand for preterm and low weight newborns, hospitalized in neonatal units in Brazil.6

Given the above, the objective of the present study was to analyze the understanding of postpartum women about the donation of HM and list the factors that motivate or hinder the possibility of becoming donors.

\section{Methods}

This is a descriptive-exploratory, quali-quantitative study, with potential mothers of HM donors, in a State Hospital, in the southern region of the State of Tocantins.

During the month of June 2018, an initial approach was carried out to invite participation in the study of pregnant women who performed prenatal care in Basic Health Units (BHU) in the municipality of Gurupi-TO, which has 13 units. The sample consisted of 1 (one) participant per BHU totaling 13 new mothers. In order to guarantee their secrecy and to preserve their identity, fictitious names were given (M1, M2, M3 ...). The pregnant woman was informed about the research and signed the Free and Informed Consent Form (FICF).

This initial link between researcher and participant aimed to make the postpartum approach more harmonious and humanized for both, since the researcher would not be completely unknown to the new mother.

After obtaining the informed consent form, the volunteer or family member made contact with the researcher, by means of a telephone call or text message, when starting labor or in the immediate postpartum period. The researcher immediately after contact went to the hospital and conducted the interview, always after the HMB's visit to the Joint Housing (ALCON). The qualitative approach allows a closer relationship with the world of meanings, of human relationships acquired through experience, making it possible to capture values, motives, operations, beliefs and attitudes. ${ }^{7}$

It was essential that the information on the understanding of the mothers was collected in the hospital environment, as the intention of the study was to verify how the understanding about HM donation would be, immediately after the delivery experience and after the visit of the HMB team to the beds, obtaining the understanding of milk donation with which the mothers leave the hospital.

The study included adult mothers, admitted to ALCON, whose children were being breastfed and who agreed to participate in the research.

Exclusion criteria were the impossibility of breastfeeding, pregnancy under the age of 19, not accepting to participate in the study or withdrawing consent at any time.

For data collection, a semi-structured questionnaire and interview script were used, in addition to the field diary, to understand the object of the study in its multiple dimensions.

The project was submitted to the Research Ethics Committee of the University of Gurupi (UnirG) and approved according to the opinion: $2,714,637 / 2018$. The socioeconomic, demographic and obstetric antecedents questionnaires were tabulated in the Microsoft Office Excel program and submitted to descriptive analyzes using the Statistical Package for Social Sciences (SPSS) 20.0 software.

For the qualitative analysis, interviews were 
recorded in audio, faithfully transcribed, on the same day of the collection, added to the descriptions of the observations and to the researcher's impressions, contained in the field diary records.

The data were processed using the NVivo Version 11 software to organize data in the qualitative research.

For data analysis, the thematic content analysis technique proposed by Bardin was used, which claims that the term of content analysis is "a set of communication analysis techniques aiming to obtain, by systematic procedures and objectives of content description messages, indicators that allow the inference of knowledge related to the production / reception conditions (inferred variables) of this message ". Consisting of the following stages: preanalysis, material exploration and treatment of results, inference and interpretation. ${ }^{7}$

\section{Results and Discussion}

The mean age of the interviewees was 24 years-old, with a minimum age of 19 years-old and a maximum of 33 years-old, and an average of $24.62 \pm 3.95$ years. A study carried out in 2012 in an HMB with SCI donors in Minas Gerais, found that the most frequent age group was between 20 and 29 years-old (48.4\%), the majority (96.8\%) of them being adults. 8 However, although this age group was the most frequent among the donors in the present study, there is evidence that demonstrates that there is no relationship between age and the practice of HM donation. 9

The socioeconomic, demographic and obstetric characteristics of the new mothers are presented in Tables 1 and 2 .

The level of maternal education constitutes a positive factor for decision, in relation to the practice of $\mathrm{BF}$ and regarding the donation of HM. The higher the level of education, the greater the access to information and, equally, the greater the ease in understanding the information, as well as the greater empowerment about the relevance of BF and donation. 10,11

Maternity pay and leave guarantee that the working woman can stay with her child at the most important moments of her life and thus breastfeed. The binomial needs to be together for several months after birth, when most of the child's brain develops and he is deeply dependent on his mother, emotionally and physiologically. 12

The short duration of maternity leave reported by the participants, or even the absence of it, can make it difficult to breastfeed and contribute to early weaning, influencing the practice of donating milk, due to the lack of the child's sucking stimulus to the mother's breast.

Most of the interviewees 69.2\% (9) had already experienced at least one pregnancy, which refers to the reasons that led these women to not have been donors of HM in previous experiences. Research carried out by Alencar and Seidl, 13 with donors from two HMB in the Federal District, shows that most of the women studied were new mothers, indicating that the practice of donation can happen simultaneously to the first experience in breastfeeding.

All mothers performed prenatal care in the public health system and it was observed that the majority of participants $(76.9 \%)$ performed the minimum number of 6 prenatal consultations recommended, denoting adequate access to health actions and services, during the current pregnancy, by the interviewees.

Regarding the previous practice of breastfeeding, $62.5 \%$ (8) performed it. However, only one interviewee $(7.7 \%)$ had breastfed exclusively until the $6^{\text {th }}$ month.

When asked how often babies should be breastfed, despite the knowledge shown, the data pointed to the practice of EBF by a small portion of the interviewees (Table 2).

The World Health Organization (WHO) and the United Nations Children's Fund (Unicef) recommend exclusive breastfeeding (EBF) until the sixth month, as it reduces neonatal and infant morbidity and mortality, in addition to promoting physical, mental and psychic health of the child and the nursing mother. 14

The II Survey on the Prevalence of BF in Brazilian Capitals and the Federal District, carried out in 2009, in relation to BF in the first six months of life, Brazil had a $41 \%$ prevalence, in the municipality of Palmas, Tocantins was $35.7 \%$, which is below the national average and WHO's and Unicef's expected goals $(60 \%) .15$

Regarding the receipt of guidance in relation to $\mathrm{BF}, 61.5 \%$ of women reported having been advised, $30.8 \%$ during hospitalization. Among the professional categories cited as the ones who implement these guidelines, nurses were mentioned $15.4 \%$ and doctors $7.7 \%$.

Table 3 shows variables that assess the degree of knowledge about milk donation and $\mathrm{BF}$ and the intentionality of the mothers regarding the donation. It was observed that the supply of milk in crossbreastfeeding has already been practiced, in previous pregnancies, by $23.1 \%$ (3) of the puerperal women 
Socioeconomic and demographic characteristics of women interviewed at the Regional Hospital of Gurupi, Tocantins, Brazil, 2018. $(n=13)$

\begin{tabular}{|c|c|c|}
\hline Characteristics & $\mathbf{N}$ & $\%$ \\
\hline \multicolumn{3}{|l|}{ Birth place } \\
\hline Gurupi - TO & 7 & 53.8 \\
\hline Other cities of Tocantins & 2 & 15.4 \\
\hline Other state & 4 & 30.8 \\
\hline \multicolumn{3}{|l|}{ Time of residence in Gurupi - TO (years) } \\
\hline$<1$ & 1 & 7.7 \\
\hline 3 & 2 & 15.4 \\
\hline $10-19$ & 4 & 30.7 \\
\hline $20-30$ & 6 & 46.2 \\
\hline \multicolumn{3}{|l|}{ Formal education (years) } \\
\hline $4-7$ & 1 & 7.7 \\
\hline $8-10$ & 1 & 7.7 \\
\hline $11-14$ & 10 & 76.9 \\
\hline 15 or more & 1 & 7.7 \\
\hline \multicolumn{3}{|l|}{ Employment situation } \\
\hline Work with a fixed job, with labor rights & 4 & 30.8 \\
\hline Self-employed, regularly & 4 & 30.8 \\
\hline Performs "home" activities & 5 & 38.4 \\
\hline \multicolumn{3}{|l|}{ Right to maternity leave } \\
\hline Yes & 4 & 30.8 \\
\hline No & 9 & 69.2 \\
\hline \multicolumn{3}{|l|}{ Maternity leave time } \\
\hline 4 months & 4 & 30.8 \\
\hline It is not applicable & 9 & 69.2 \\
\hline \multicolumn{3}{|l|}{ Marital status } \\
\hline Married & 4 & 30.8 \\
\hline Stable union & 6 & 46.1 \\
\hline Single & 3 & 23.1 \\
\hline \multicolumn{3}{|l|}{ Family income (minimum wages) } \\
\hline Up to 2 & 10 & 76.9 \\
\hline $3-4$ & 3 & 23.1 \\
\hline \multicolumn{3}{|l|}{ Live with } \\
\hline Husband and children & 7 & 53.8 \\
\hline Relatives & 3 & 23.1 \\
\hline Child & 2 & 15.4 \\
\hline Husband & 1 & 7.7 \\
\hline
\end{tabular}

and, in all cases, the breastfed children were relatives of the nursing mothers. Likewise, $15.4 \%$ (2) of the interviewees have already allowed cross-breastfeeding to their children.

The occurrence of cross-breastfeeding still frequently raises concern due to the risks it offers to child's health. Being aware that the risk of a woman carrying the human immunodeficiency virus (HIV) and transmitting the virus through breastfeeding is between 7 and $22 \%$ and that this risk is renewed at each feeding, the Ministry of Health contraindicates cross-breastfeeding, as such practice puts the child's health and life at risk, causing an incurable disease that promotes a limited, suffered existence and/or premature death. In addition, other diseases and contaminants of HM (drugs, alcohol, tobacco, sweeteners, caffeine, chemical substances of environmental or occupational exposure, etc.) can also be transmitted. 16

Four of the interviewees (M1, M6, M12, M13) 
Table 2

Obstetric characteristics of women interviewed at the Regional Hospital of Gurupi, Tocantins, Brazil, 2018 (N=13).

\begin{tabular}{|c|c|c|}
\hline Characteristics & $\mathbf{N}$ & $\%$ \\
\hline \multicolumn{3}{|l|}{ Number of pregnancies } \\
\hline 1 & 4 & 30.8 \\
\hline$>1$ & 9 & 69.2 \\
\hline \multicolumn{3}{|c|}{ Death of previous child before 1 month of life } \\
\hline No & 7 & 69.2 \\
\hline It is not applicable & 6 & 30.8 \\
\hline \multicolumn{3}{|l|}{ Mode of delivery - last pregnancy } \\
\hline Normal & 3 & 23.0 \\
\hline Cesarean & 5 & 38.5 \\
\hline It is not applicable & 5 & 38.5 \\
\hline \multicolumn{3}{|l|}{ Pre-natal care - current pregnancy } \\
\hline Yes & 13 & 100.0 \\
\hline \multicolumn{3}{|l|}{ Number of prenatal consultations } \\
\hline 10 & 4 & 30.8 \\
\hline 9 & 2 & 15.4 \\
\hline 8 & 2 & 15.4 \\
\hline 6 & 2 & 15.4 \\
\hline 5 & 3 & 23.0 \\
\hline \multicolumn{3}{|l|}{ Prenatal network } \\
\hline Public & 13 & 100.0 \\
\hline \multicolumn{3}{|l|}{ Breastfeeding the last child } \\
\hline Yes & 8 & 61.5 \\
\hline It is not applicable & 5 & 38.5 \\
\hline \multicolumn{3}{|c|}{ Duration of previous breastfeeding (months) } \\
\hline 4 & 1 & 7.7 \\
\hline 6 & 1 & 7.7 \\
\hline $7-11$ & 2 & 15.4 \\
\hline $12-24$ & 3 & 23.0 \\
\hline $25-36$ & 2 & 15.4 \\
\hline It is not applicable & 4 & 30.8 \\
\hline \multicolumn{3}{|l|}{ Exclusive breastfeeding } \\
\hline Yes & 5 & 38.5 \\
\hline No & 3 & 23.0 \\
\hline It is not applicable & 5 & 38.5 \\
\hline \multicolumn{3}{|c|}{ Duration of exclusive breastfeeding (months) } \\
\hline 1 & 2 & 15.4 \\
\hline 4 & 2 & 15.4 \\
\hline 6 & 1 & 7.7 \\
\hline It is not applicable & 8 & 61.5 \\
\hline \multicolumn{3}{|c|}{ Receiving guidance on breastfeeding } \\
\hline Yes & 8 & 61.5 \\
\hline No & 5 & 38.5 \\
\hline \multicolumn{3}{|c|}{ Moment that received guidance on breastfeeding } \\
\hline Prenatal & 2 & 15.4 \\
\hline Hospitalization & 4 & 30.7 \\
\hline Prenatal and hospitalization & 2 & 15.4 \\
\hline It is not applicable & 5 & 38.5 \\
\hline \multicolumn{3}{|l|}{ Professional who guided } \\
\hline Nurse & 2 & 15.4 \\
\hline Doctor & 1 & 7.7 \\
\hline Did not appear & 2 & 15.4 \\
\hline It is not applicable & 7 & 38.5 \\
\hline Do not remember & 5 & 23.0 \\
\hline
\end{tabular}


Knowledge about breastfeeding, human milk donation and intentionality of donation of mothers interviewed at the Regional Hospital of Gurupi, Tocantins, Brazil, $2018(\mathrm{~N}=13)$.

\begin{tabular}{|c|c|c|}
\hline Donation knowledge and intentionality & $\mathbf{N}$ & $\%$ \\
\hline \multicolumn{3}{|l|}{ Cross-breastfed milk supply } \\
\hline Yes & 3 & 23.0 \\
\hline No & 5 & 38.5 \\
\hline It is not applicable & 5 & 38.5 \\
\hline \multicolumn{3}{|l|}{ Type of connection with the breastfed child } \\
\hline From a relative (sister, cousin, etc.) & 3 & 23.1 \\
\hline It is not applicable & 10 & 76.9 \\
\hline \multicolumn{3}{|l|}{ Allowed cross-breastfeeding with her child } \\
\hline Yes & 2 & 15.4 \\
\hline No & 6 & 46.1 \\
\hline It is not applicable & 5 & 38.5 \\
\hline \multicolumn{3}{|l|}{ When to breastfeed your child } \\
\hline Free demand & 7 & 53.8 \\
\hline 3 in 3 hours & 4 & 30.8 \\
\hline 2 in 2 hours & 1 & 7.7 \\
\hline 1 in 1 hour & 1 & 7.7 \\
\hline \multicolumn{3}{|c|}{ Exclusive breastfeeding recommendation (months) } \\
\hline 1 & 2 & 15.4 \\
\hline 4 & 3 & 23.0 \\
\hline 5 & 1 & 7.7 \\
\hline 6 & 6 & 46.2 \\
\hline Never & 1 & 7.7 \\
\hline \multicolumn{3}{|c|}{ Is there a situation in which breastfeeding is contraindicated? } \\
\hline Yes & 9 & 69.2 \\
\hline No & 4 & 30.8 \\
\hline \multicolumn{3}{|c|}{ Does the HM have a similar composition from the } \\
\hline \multicolumn{3}{|c|}{ beginning to the end of the feed? } \\
\hline Yes & 3 & 23.1 \\
\hline No & 10 & 76.9 \\
\hline \multicolumn{3}{|c|}{ Have you ever been a donor (milk, blood, organs)? } \\
\hline Yes & 1 & 7.7 \\
\hline No & 12 & 92.3 \\
\hline \multicolumn{3}{|c|}{ How many times have you donated human milk? } \\
\hline 6 times & 1 & 7.7 \\
\hline It is not applicable & 12 & 92.3 \\
\hline \multicolumn{3}{|c|}{ If you had the chance, would you donate human milk? } \\
\hline Yes & 11 & 84.6 \\
\hline No & 1 & 7.7 \\
\hline It is not applicable & 1 & 7.7 \\
\hline
\end{tabular}

$\mathrm{HM}=$ Human milk.

reported complications with breastfeeding, requiring the return of the researcher at another time or another day to conduct the interview, in order to collect data at a more suitable time for the mother Only one of the mothers (M1) among the interviewees had already donated milk.

\section{Categorization}

From the reading of the interviews, the Registration Units were elaborated and through them the Elementary Context Units were determined, looking for segments of the testimonies that would help better understanding for coding, as shown in Table 
4. The final three categories of analysis were: Understanding about breastfeeding; Health education for improving knowledge and Relation of factors associated with milk donation, and they are shown in Table 5 .

\section{Table 4}

Registration Units and Elementary Context Units identified in the interviews with mothers from the Regional Hospital of Gurupi, Tocantins, Brazil, 2018.

\begin{tabular}{lc}
\hline Registration Units & Context Units \\
\hline
\end{tabular}

Pleasure in breastfeeding

Perseverance in suckling

Understanding of obligation regarding breastfeeding

Feelings involved in breastfeeding

Recognition of breastfeeding and donation as importante

Ease of breastfeeding

Bad current experience

Painful experience

Experience with breastfeeding

Absence of milk

Knowledge about healthy growth and development

Knowledge about human milk benefits

Adequate guidance by the health team

Inadequate guidance by the health team

Knowledge acquired in the previous pregnancy

Health promotion

Guidance received through observation, pamphlets, newspa-

per and internet

Guidelines received by health professionals

Suggestion of disclosure of breastfeeding, since the beginning

of prenatal care, lecture on admission and discharge

Affinity for receiving guidance through conversation and lec-

Media for awareness raising

ture

Unavailability of time to leave home

I wouldn't donate milk

Difficulty in milk production

Reasons for not donating human milk

Difficulty in collecting milk

Doesn't know HMB

Don't know the donation process

Excess of milk production

Donation in order to help others, charity and empathy

Donate milk

Reasons for donating human milk

Dificuldade de coleta de leite

Know the $\mathrm{HMB}$

Disclosure of the role of the HMB

$\mathrm{HMB}=$ Human Milk Bank 
Final categories of analysis of the interviews with mothers from the Regional Hospital of Gurupi, Tocantins, Brazil, 2018.

\begin{tabular}{ll}
\hline Elementary Context Units & \multicolumn{1}{c}{ Final Categories of Analysis } \\
\hline & \\
- Feelings involved in breastfeeding & I - Understanding about breastfeeding: \\
- Experience on breastfeeding & $\begin{array}{l}\text { It presents the understanding of the mothers about BF, } \\
\text { describing feelings and experience. }\end{array}$ \\
- Knowledge on benefits of human milk. &
\end{tabular}

- Health promotion

- Media for awareness raising
II- Health education for knowledge improvement: It describes what is expected by women, in relation to health promotion, given the donation of milk and BF in the pregnancy-puerperal cycle.

III- List of factors associated with milk donation: List of facilitating and limiting factors for HM donation, according to the interviewed mothers.

$\mathrm{BF}=$ breastfeeding; $\mathrm{HM}=$ human milk.

\section{Understanding about breastfeeding}

Breastfeeding is fundamental to children's health, due to its nutritional, emotional, immunological, socioeconomic and developmental benefits, in addition to maternal health benefits. BF is the ideal feeding practice for infants in the first six months of life, since its advantages are irrefutable, both from a biological and psychosocial point of view. 17,18

When asked about the current experience with breastfeeding, four of the interviewees reported difficulties (M1, M2, M12 and M13) and presented the following statements:

"[...] it's being a little difficult, my nipple has cracked, then it hurts a lot, but we have to breastfeed, we can take the pain and breastfeed [...]". (M1)

“[...] my experience with breastfeeding is not being very pleasant (laughs), how can I say... right? Because I have not been having milk at the moment to breastfeed the baby and there it is, like, a frustration for us, for me mainly". (M2)

"[...] despite the regrets, 'it's' being good (laughs), it's a new experience, 'it's' being good, getting used to this new one". (M12)

"[...] it's being horrible because I'm not able to breastfeed, because the boy is not able to catch because of the nipple." (M13)
Through the speeches, despite the initially negative experiences, the mothers showed optimism and persistence regarding the continuity of breastfeeding, it is inferred that these expressions may be the result of the mothers' understanding of the maternal role during the act of breastfeeding.

A study in which the Unicef evaluation protocol was applied, demonstrated, based on the analysis of 152 binomials admitted under the ALCON regime, that $55 \%$ of them had at least one difficulty in the BF. 19

It was observed that mothers use different efforts to offer HM to their child. BF should not be understood as an imposed and obstacle-free activity. Reports of pleasant experiences with breastfeeding were expressed in the excerpts of the following speeches:

"[...] I really like to breastfeed my children, very much! My experience is very good! [...] ". (M10)

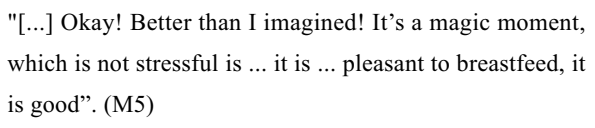

A qualitative research, carried out with 20 nursing mothers in the city of Rio de Janeiro, reported that $\mathrm{BF}$ has different meanings and representations for the female universe, however, all the interviewees converged on a practice aimed essen- 
tially at the child's needs. The survey showed that not every woman enjoyed this practice (15\%). Despite being breastfeeding, three women admitted their desire to finish as soon as possible, or stated that they simply did not like to breastfeed. 20

Breastfeeding is an act not perceived in a similar way by all women. Each nursing mother experiences the experience in a peculiar way: for some it is an act of extreme pleasure, happiness and reward; for others, it can be painful and painful. Many women reported feeling breastfeeding as an obligation to be fulfilled and, even in suffering, breastfed.21

\section{Health education for improving knowledge}

When asked how they received guidance on breastfeeding, two interviewees in the present study reported they did not receive any guidance.

"No". (M4)

"I did not receive it". (M8)

Family members had their support reported in the interviews, with $30 \%$ of the puerperal women reporting that the guidelines on BF came from them.

"The things that I know, right? My mother who teaches me, right? But I didn't receive any information like that". (M1)

“[...] I didn't receive much guidance ... the guidance we have is from other people, right? So, family members ... these things..." (M3)

"[...] in the first pregnancy I participated in a lecture on breastfeeding. The rest is my mom and my grandmother who teach me". (M6)

"In reality, like this, some people 'told me' even at the health center ... and my mother, my mother was the main one, she always said that breastfeeding is very important so it really comes from home [...]". (M10)

Through the speeches, it is observed that the mothers studied here wish to receive information about BF and milk donation through dialogue or lectures, and consider the information provided in the prenatal and puerperium to be relevant. One interviewee mentioned the use of the internet as a means of obtaining information.

"I don't like pamphlet. I like people to 'explain', talk to us, and we understand it. I don't read the pamphlet, I won't lie". (M1)

"[...] I think they should give more guidance, like, in the past people used to lecture. Health centers now no longer have the lectures that were 'given' at the beginning of prenatal care [...]". (M2)

"I think there should be more publicity, right? ... More lecture. At the same unit". (M5)

"[...] I think the ideal is 'when' we have the baby, mothers always participate in a lecture before being discharged, I don't know ...". (M6)

"[...] when we get there in the pre-delivery room, they could give a lecture to explain us, both about breastfeeding and other topics that are 'accurate'. Like 'the strength': nobody knows how it is! ”. (M9)

"[...] it is important for us to receive guidance from the beginning, because you are already learning, right? ... it is ... in the 'past' of the months you are already learning, you are acquiring knowledge on the subject, the importance also of donating milk [...]”. (M8)

“[...] the way I've received is cool, through social networking, leafleting ... I'm even very curious, I ask questions and interact 'with a subject ... and it's quiet!". (M11)

The health team must take advantage of the impact of the educational process, as it cooperates to bring people together and to strengthen the singular and collective potential, with regard to the valorization of health, the use of available resources and the exercise of citizenship.

Strategies are necessary to facilitate the spread of information about the anatomical, physiological and immunological foundations of breastfeeding; in relation to the clinical management of breastfeeding and breast complications. Health professionals must be able to provide correct information, acting creatively, using the advantages and importance of $\mathrm{BF}$ as allies in convincing women to breastfeed, reconciling this practice with other roles practiced by women in society. It is the duty of all health professionals, especially those who work with the pregnancy-puerperal cycle, to act as agents of health promotion, positively influencing the practice of BF. 22 
Relation of factors associated with milk donation

As they can be seen in the following speeches, the factors that may make it difficult to donate milk are: lack of knowledge about the donation process; the little time available; and the lack of means of transport and HM collection points.

“[...] I've never participated in a conversation about it ... donating breast milk. So I know there is a lot of little baby who needs it, but I think I wouldn't donate, you know, I think it's even lack of information, but I wouldn't leave the house to go to a health center to deliver milk. I think it's weird!". (M6)

"[...] it is a matter of time, availability to leave home... it is more complicated there 'to help'. We can't keep talking, right? Each case is different. There are people who have a car to come here; there are people who don't, right? So think that 'for' people 'can' be donors, they should have easier access 'for people'... not just a bank here, right? But closer banks, in other sectors". (M1-ex-donor)

The literature suggests that, in order to alleviate the difficulties encountered by mothers, and to encourage HM donation, lectures with women in the prenatal period are strategic, a moment when you can also invite them to visit the HMB, even during pregnancy, showing them the recipients of donated HM, the processing steps of raw donated HM.23 Such strategies are feasible to be implemented by the HMBs.

Regarding the factors that encourage donation, altruism was a feeling that appeared in several statements in the present study; as well as the feeling of empathy towards other mothers who, for some reason, were unable to breastfeed. In addition, it was possible to identify that the interviewees understand the importance of $\mathrm{HM}$ and its primacy in relation to commercial formulas and other milks.

"[...] it's very pleasurable, because the donation of milk is like helping another person, another baby. You are the mother of another child's milk, right? So I think it is very important to donate milk". (M2)

"[...] it's a good gesture, right? Yes, helping other people ... the gesture is beautiful, it helps to save a lot of 'life', right? (laughs)". (M3)

"I think it is very sad that the child does not have ... any breastfeeding period, and going to drink other milk, right?". (M5)
"Hey, very good! Because if she 'got it', right? Breastfeeding the child and donating to other children is very good, because breast milk is very important! ". (M7)

"[...] one thing I know, breast milk is very important 'for' baby, 'for' newborn, so no other milk replaces breast milk". (M8)

"[...] if the person has enough, it donates to those who need it, because breast milk is fundamental for the child's development, 'for' it does not give disease ... so much ... If the person has it for donation, donate! Yes, it is important!". (M9)

"[...] helping the other little children who 'need' [...] It is important to breastfeed or donate milk". (M10)

"I think she is feeding another life. So, if I have 'for' me, 'for' 'my baby, why not giving this to a mommy who didn't have it [...]". (M11)

"[...] it's good for us to know that a child is breastfeeding, in addition to ours!" (M12)

"Ah! It's very good, because there's a lot, right? It's still

'for' her and 'others', it's too good, 'boy'! ”. (M13)

These results are similar to those of a study carried out with donors from an HMB in Cuiabá-MT, which pointed out that the donation was perceived as a solidarity action. It is also relevant to consider that the social context in which the woman is inserted significantly influences her understanding of the dimensions of the donation. In this way, the influence of people close to the nursing mother, such as the spouse; in addition to institutional support, they operate positively towards the predisposition to donate milk. ${ }^{24}$

The study leads to the reflection that culture, tradition, values that impose on society during pregnancy can influence breastfeeding.

Still regarding the reasons that would lead to the act of donation, the excess of milk production is mentioned in the speech of M13, and the concern that the donation does not harm the child's own nutrition, mentioned in the speech of M8:

"If I had a lot of milk, I would donate, right?" (M13)

“[...] to help other children, right? As long as I don't miss my son, (laughs) it is [...] I don't see any problem in being a milk donor, as long as I supply my son and can also help other babies". (M8) 
A study carried out in an HMB in Tubarão-SC, also listed the excess of milk production, in second place, as a predisposing factor to the attitude of donating, having been mentioned by $22.2 \%$ of the donors. 25

A quantitative study, with donors of an HMB, showed that, among the reasons considered most important for donation, was the feeling of benevolence in helping children who need SCI. ${ }^{26}$

This feeling of benevolence in helping other children was also evident in this study, as can be seen in the following speeches:

"Ah! ... knowing what a child needs, right? To know that you need it ... I think I would donate... no problem!”. (M3)

"For me, knowing that a child is in need ... in need of food and I have it, why don't I give it?" (M4)

"[...] breast milk is very important and there are many children who need breast milk, there are many mothers who cannot give breast milk, right? It is... the breast, the milk". (M7)

"Ah! 'To' help the other little children who 'need' it" (M10)

The only nursing mother interviewed in this study, who had previously been a donor, says that the current pregnancy transformed her understanding of donation, as her baby needed to receive supplementation, due to low colostrum production, and this fact made her rethink the reasons donation. When she was a donor before, the reason was the excess of milk production

"I think that now I would donate, as we understand [...]

my son is here, right? He had to receive milk, because he

was hungry, so it's already something ... if we donate it

will not make other people hungry, I thought about it now too ...". (M1)

Regarding her experience with donation, M1 states that she received support from her sister, who had no difficulty in donating:

“No, it's just my sister, is it?" (M1)

When asked if there was any difficulty with the donation, she reported how difficult the transport problem was to send milk to the HMB, but when she needed the HMB's assistance, she felt welcomed.
"The question of access, that's all. The facility only if we 'came' here they serve us well, right?'

The interviewees listed as alternatives for attracting new donors: facilitating transport for the sending of milk, carrying out dissemination actions, informing the importance and function of the HMB; and clarification about the destination of the donated milk. They emphasized that they would like to receive information during the prenatal period.

"Just the question of access, that's all!" (M1- ex-donor)

"I think it should promote more actions, 'mobilizing' the population". (M2)

“[...] because sometimes the person has a lot of milk, but there was no guidance, right? There was no encouragement from anyone, they 'stop donating' for lack of encouragement". (M7)

"Raising awareness of mothers who are pregnant, who are 'having' baby, raising awareness of the importance of milk donation". (M8)

“[...] many people, who don't know the function, don't know why it works. It doesn't work like that, as it is important, there is no information, so information is the most accurate way". (M9)

"Giving more lecture, right? Because at the health center, it's very little, right? They hardly speak, do not divulge, do not have, do not have a lecture ... Just like I came from the health post and I did not see any lecture, so I think they are not very 'interested' no”. (M10)

“[...] try to open the mothers' minds a little more and, maybe they think that milk, many of them that I've seen question that: ah! They will collect my milk and they will not use it, they will throw it away!”. (M11)

\section{Field diary}

It was observed through the field diary and the interviewees' speeches, that they almost always use the third person of the verbal conjugation, that is, they do not seem to see themselves as possible donors, they just seem to be expressing their opinion about the act of donating. Thus, it is emphasized that the ignorance of the processes that involve the donation of milk by the studied population can make the donation act more difficult, in addition to distancing the volunteer woman from the process, leading her to 
believe that it is a complex and unlikely practice in reality.

The results of this study can help health services to establish new strategies for attracting potential donors. The HMB, as a public institution that aims to stimulate and to promote breastfeeding, should use health education to improve the understanding of pregnant women about the process involved in the donation of milk, attracting new potential donors and, thus, fulfill their objectives of collecting and distributing HM, meeting the needs of its receivers. Although breastfeeding is considered instinctive and natural, women need to be taught and supported during pregnancy and puerperium, since breastfeeding failure directly influences the practice of HM donation.

The puerperal women showed feelings of empathy and altruism as motivational factors. The data indicate that the nursing mothers understand the superiority of HM in relation to other milks and the importance of donating it, however there is still a need for further guidance, especially in prenatal care, regarding the function of the HMB, benefits of the donation, form transportation and destination of donated milk, since they are factors that sensitize donation in the mothers' view.

This research suggests the need for future studies, which list support indicators for popular health education actions by the service, guiding the making of more effective pedagogical material for dissemination of HM donation, by health profes-

\section{References}

1. Brasil. Ministério da Saúde. Banco de leite humano: funcionamento, prevenção e controle de riscos. Brasília DF; 2008.

2. Brasil. Ministério da Saúde. Secretaria de Atenção à Saúde. Departamento de Ações Programáticas Estratégicas. Bases para a discussão da Política Nacional de Promoção, Proteção e Apoio ao Aleitamento Materno. Brasília, DF 2017. $68 \mathrm{p}$.

3. Rede Global de Bancos de Leite Humano. Comunidade dos Países de Língua Portuguesa. A criação da rede de bancos de leite humano da Comunidade dos Países de Língua Portuguesa. Rio de Janeiro: IFF/FioCruz; 2017. 38p.

4. Rede Brasileira de Bancos de Leite Humano. Bancos de Leite Humano - Localização e Relatórios. [acesso em set 2019]. Disponível em: https://producao.redeblh.icict. fiocruz.br/portal_blh/blh_brasil.php.

5. Brasil. Ministério da Saúde. Secretaria de Atenção à Saúde. Departamento de Ações Programáticas Estratégicas. Atenção humanizada ao recém-nascido de baixo peso: Método Canguru: manual técnico. 2 ed. Brasília, DF; 2013. $204 \mathrm{p}$ sionals in pre-primary care services for pre-natal and birth.

\section{Final considerations}

Although feelings of empathy and altruism have stood out as motivational factors for donation, the misinformation of mothers about milk donation and the functioning and performance of human milk banks makes milk donation a complex and distant act from the reality of potential donors.

However, the participants were receptive to information and support regarding breastfeeding and milk donation, in the approaches by the health service during care received in the pregnancy-puerperal cycle, which points to popular health education as a strategy to be adopted for the service.

In health education actions, the team must include the people around the puerperal woman, identified as key supporters in this study.

\section{Authors' contribution}

Buges NM performed data collection and analysis, writing of the article. Klinger KAS carried out the methodological conception and data analysis. Pereira RJ participated in the research conception, data analysis and writing of the article. All authors approved the final version of the article.
6. Brasil. Ministério da Saúde. Ministério da Saúde lança campanha de divulgação de doação de leite humano; 2017 [acesso 2 mar 2019]. Disponível em: http://dab.saude. gov.br/portaldab/noticias.php?conteudo $=\& \operatorname{cod}=2366$

7. Bardin L. Análise de Conteúdo. Lisboa, Portugal: Edições 70 LDA; 2009

8. Fonseca-Machado MOF; Parreira BDM; Dias FA; Costa NS; Monteiro JCS; Gomes-Sponholz FG. Caracterização de nutrizes doadoras de um banco de leite humano. Ciênc Cuid Saúde. 2013; 12 (3): 529-38

9. Vieira MLF, Silva JLC, Barros Filho AA. A amamentação e a alimentação complementar de filhos de mães adolescentes são diferentes das de filhos de mães adultas? J Pediatr. 2003; 79 (4): 317-24.

10. Abreu JN, Alves YJ, Pereira S, Lobato JSM, Foutoura IG, Neto MS, Santos FS. Doação de leite materno: fatores que influenciam para esta prática. Arq Ciênc Saúde. 2017; 24 (2): 14-8. Disponível em: http://www.cienciasdasaude. famerp.br/index.php/racs/article/view/548/684

11. Neves LS, Sá MV, Mattar MJ, Galisa MS. Doação de leite 
humano: dificuldades e fatores limitantes. Mundo Saúde 2011; 35 (2). [acesso 16 fev 2019]. Disponível em: http://www.saocamilo-sp.br/pdf/mundo_saude/84/156161.pdf

12. Calnen G. Paid Maternity Leave and Its Impact on Breastfeeding in the United States: An Historic, Economic, Political, and Social Perspective. Breastfeed Med. 2007; 2 (1): 34-44.

13. Alencar LCE, Seidl EMF. Doação de leite humano: experiência de mulheres doadoras. Rev Saúde Pública. 2009; 43 (1): 70-7.

14. WHO (World Health Organization). The optimal duration of exclusive breastfeeding - Report of an Expert Consultation - Geneva, Switzerland; 2001. [acesso $14 \mathrm{fev}$ 2019]. Disponível em: http://www.who.int/nutrition/publications/optimal_duration_of_exc_bfeeding_report_eng.pdf

15. Brasil. Ministério da Saúde. II Pesquisa de prevalência de aleitamento materno nas capitais brasileiras e Distrito Federal. Brasília: Ministério da Saúde; 2009. [acesso 10 jun 2016]. Disponível em: <http://bvsms.saude.gov.br/bvs/ publicacoes/pesquisa_prevalenciaaleitamentomaterno.pdf $>$.

16. Brasil. Ministério da Saúde. Secretaria de Vigilância em Saúde. Programa Nacional de DST e Aids. Protocolo para a prevenção de transmissão vertical de HIV e sífilis: manual de bolso. Ministério da Saúde: Brasília, DF; 2007. [acesso 13 mar 2019]. Disponível em: http://bvsms.saude.gov.br/ bvs/publicacoes/protocolo_prevencao_transmissao_verticalhivsifilis_manualbolso.pdf

17. Almeida JM, Luz SAB, Ued FV. Apoio ao aleitamento materno pelos profissionais de saúde: revisão integrativa da literatura. Rev Paul Pediatr. 2015; 33 (3): 355-62. Disponível em: https://www.sciencedirect.com/science/ article/pii/S0103058215000702

18. Rito AI, Buoncristiano M, Spinelli A, Salanave B, Kunesová M, Hejgaard T, García Solano M, Fijałkowska A, Sturua L, Hyska J, Kelleher C, Duleva V, Musić Milanović S, Farrugia Sant'Angelo V, Abdrakhmanova S, Kujundzic E, Peterkova V, Gualtieri A, Pudule I, Petrauskiené A, Tanrygulyyeva M, Sherali R, Huidumac-Petrescu C, Williams J, Ahrens W, Breda J. Association between characteristics at birth, breastfeeding and obesity in 22 countries: The WHO European Childhood Obesity Surveillance Initiative - COSI 2015/2017. Obes Facts. 2019; 12 (2): 226-43.
19. Mosele PG, Santos JF, Godói VC, Costa FM, Toni PM, Fujinaga CI. Instrumento de avaliação da sucção do recém nascido com vistas a alimentação ao seio materno. Rev CEFAC. 2014; 16: 1548-57.

20. Marques DM, Pereira AL. Amamentar: sempre benefícios, nem sempre prazer. Ciênc Cuid Saúde. 2010; 9 (2): 214-19.

21. Signor E, Silva LAA, Gomes IEM, Ribeiro RV, Kesler M, Weiller TH, et al. Educação permanente em saúde: desafios para a gestão em saúde pública. Rev. Enferm UFSM. 2015; 5 (1): $1-11$

22. Freitas GL, Joventino ES, Aquino PS, Pinheiro AKB, Ximenes LB. Avaliação do conhecimento de gestantes acerca da amamentação. Rev Min Enferm. 2008; 12 (4) 461-8.

23. Alencar LCE, Seidl, EM. Breast milk donation and social support: reports of women donors. Rev Latinoam Enferm. 2010; 18 (3): 381-9.

24. Silva ES, Jesus LE, Batistela E, Castro NA, Fonseca LB Doação de leite materno no banco de leite humano: conhecendo a doadora. Demetra. 2015; 10 (4): 879-89.

25. Lourenço D, Bardini G, Cunha L. Perfil das doadoras do banco de leite humano do Hospital Nossa Senhora da Conceição, Tubarão/SC. Arq Catarin Med. 2012; 41 (1): 22-

26. Weschenfelder S, Peixoto HM, Martins RGG Levantamento dos aspectos sociodemográficos e motivacionais em doadoras de leite humano. Rev Enferm UFPE. 2012; 6 (2): $267-73$

Received on April 25, 2019

Final version presented on October 10, 2019

Approved on December 27, 2019 